\title{
Analysis of E-commerce of Agricultural Cooperatives in Jiangxi
}

\section{Province}

\author{
Liu Shanqing, Xiong Zhengyu \\ (Jiangxi Normal University, Nanchang 330022, China) \\ (Jiangxi Normal University, Nanchang 330022, China) \\ Liushanqing88@163.com,1297648859@qq.com
}

Key words: Jiangxi Agricultural Cooperatives; e-commerce; development proposal

Abstract: Based on the current development trend of e-commerce of agricultural cooperatives, this thesis proceeds from reality of Jiangxi Province, makes a research on the development of e-commerce in Jiangxi agricultural cooperatives, and then analyzes the present situation and existing problems of e-commerce in Jiangxi agricultural cooperatives. In addition, a further analysis of cause is performed on the main problems. Finally the author puts forward several reasonable proposals on the acceleration of development of e-commerce in Jiangxi agricultural cooperatives.

\section{Introduction}

Agricultural cooperative, based on the rural household contract, is a mutual economic organization that producers with similar agricultural product or suppliers and users with similar farmers' production service unite in terms of voluntary association and democratic management. Agricultural cooperative regards its members as the main target of service and assists farmers to purchase producing information, to sell, process, transport, store agricultural products, as well as other technology, information about farmers' production and operation [1]. Agricultural cooperative is able to optimize the allocation of agricultural resources and to accelerate the development of modern agriculture. With the development of modern information technology, the e-commerce model of agricultural cooperatives has been widely used in some developed countries and regions, and excellent results have been achieved. However, Jiangxi, as a major agricultural province, is still backward in the field of agricultural cooperatives in e-commerce. This thesis analyzes the problems of e-commerce development of agricultural cooperatives in Jiangxi Province. In order to accelerate the pace and enhance the level of modern agriculture in Jiangxi, the thesis also puts forward proposals on the development of agricultural cooperatives in Jiangxi Province.

\section{Analysis of e-commerce development in Jiangxi Agricultural Cooperatives}

Jiangxi is a major province with rich agricultural resources where agricultural accounts for a large proportion of the gross production. Jiangxi has a land area of 166,900 square kilometers, of which 50,100 square kilometers are mountainous areas, 70,100 square kilometers are hilly areas, and 16,700 square kilometers are watery areas [2]. Despite the abundant agricultural resources in Jiangxi, for a long time, low degree of industrialization of agriculture, and lack of agricultural science and technology resulted in inadequate utilization of agricultural resources, the lack of deep processing of agricultural products, low agricultural efficiency. In recent years, however, in order to improve the comprehensive level of agricultural, Jiangxi Province starts to speed up the 
industrialization process of agriculture, particularly on the construction of agricultural cooperatives.

After China promulgated the "Agricultural Cooperatives" in 2006, Jiangxi has been developing agricultural cooperatives and introduced over 40 policies and regulations to support the professional development of cooperatives. Since 2009, annual special fund of no less than 20 million Yuan in Jiangxi Province has been established to improve infrastructure, to construct standardized base, to carry out the relevant technical training, to implement the brand management, and finally to provide the "Agriculture to Supermarket" with services. At the end of 2014, there were 35,300 professional agricultural cooperatives in Jiangxi through industrial and commercial registration whose total investment was 76.782 billion Yuan with 643,500 total members. The average member of cooperatives in Jiangxi Province reached 18.2. There were 1200 cooperatives with 50-100 members, 2000 cooperatives with 100-500 members, 47 cooperatives with 500-1000 members, and 4 cooperatives with over 1,000 members.

Agricultural cooperatives have been the main power to help farmers to make structural adjustments and to accelerate the formation of local industrial belts or industrial groups. Every cooperative, according to their own characteristics of industry and their advantages of the product, organizes specialization of members and scale of production so that it effectively promotes the characteristic development of regional economic. Currently, Jiangxi Province has constructed the fruits production base mainly with navel oranges of Gannan, aquatic breeding base mainly with crabs and shrimps around Poyang Lake and production base with environmental rice. All cooperatives closely connect small-scale production of thousands of households to the large ever-changing markets. As a result, it contributes to the industrial management of farmers and members of cooperatives increase income directly in distribution of profits and capital stock dividends, etc.

At present, as the construction of agricultural cooperatives, Jiangxi helps them mainly with capital investment, technical assistant, and also the industrialization of agriculture has formed a certain scale. However, comparatively speaking, the construction of Jiangxi agricultural cooperatives of e-commerce lags far behind, and its level is still very low mainly in these ways: the application of e-commerce of agricultural cooperatives are mostly restricted in the simple way of products sale; and in terms of the technological exchanges of industry products and the resource integration and information sharing, it is rarely applied. What's more, the scope of e-commerce is still relatively small. Many agricultural products are simply published with pictures and text in a number of informational websites, and e-commerce products does not sell too many. E-commerce of agricultural cooperatives cannot grow much bigger if only by some farmers with higher-education and proficiency about the internet. Meanwhile, due to the lack of professionals, the primary system of the e-commerce of cooperatives that had been built is not effectively safeguarded so that it cannot get function. In addition, as the short shelf life of agricultural products and efficiency of rural logistics is not high, many agricultural products in the circulation of electronic business cannot be guaranteed on quality. As a consequence, it has a direct impact on the reputation of the product.

\section{The main reasons for the slow development of e-commerce of agricultural cooperatives in Jiangxi}

E-commerce of agricultural cooperatives in Jiangxi started lately, and developed slowly, so that its comprehensive level is pretty low. According to field researches and serious consideration of the local situation in Jiangxi, the author analyzes and summarizes these reasons for the slow development of e-commerce of agricultural cooperatives in Jiangxi as follows: 
The Government did not attach great importance to e-commerce when constructing agricultural cooperatives.

For many years, the Government of Jiangxi Province mainly stressed industrialization, large-scale, capital, technology in times of the construction of agricultural cooperatives instead of the aspect of e-commerce of it. As we all know, it is clearly incorrect to neglect e-commerce nowadays. Wrong consciousness is a direct reason for the slow action, even for the no action, thus leading to obvious deficiency of the e-commerce development of agricultural cooperatives

The internet penetration in rural areas is low and most farmers lack a full understanding of ecommerce

Generally speaking, the internet penetration in rural areas of Jiangxi is very low; people there do not get higher education; most households do not have a strong demand for the internet; and there is still a distance between each application on the Internet and their real-life. Therefore, it failed to stimulate their learning and acceptance of e-commerce in agriculture [3]. Not familiar with the network, many farmers do not understand e-commerce at all, let alone the benefits of e-commerce. As a result, it is hard for the construction of e-commerce of agricultural cooperatives to move forward.

Application mode of agricultural cooperatives e-commerce is too single to explore relevant markets about electricity business applications

Now, application mode of agricultural cooperatives e-commerce in Jiangxi is still relatively single. Mostly farmers take the B2C model which puts agricultural products for sale on the internet in aid of basically mature third-party trading platform [4]. E-commerce is simply used for sale. Until now, Jiangxi has not owned a professional and integrated online trading platform with popularity led by the government or relevant industry associations. Also mutual cooperation between electricity suppliers and agricultural enterprises is relatively limited。As a result, wide markets of electricity supplier have not been fully utilized for agricultural cooperatives.

Information asymmetry between electricity-provider markets and agricultural products leads to difficulty in carrying out e-commerce of agricultural cooperatives

Because of asymmetry of market information of electric providers, many consumers fail to identify the authenticity of the product all the time. Rational consumers can not completely believe it and take a lot of them through a product presentation. Furthermore, consumers are unable to safeguard their rights if the inferior products came from electricity-supply markets. Therefore, the problem of quality and crisis of sellers' credit resulting from it, to a large extent, put an end to e-commerce activities of agricultural cooperatives.

Distribution channels of agricultural products do not work well, hindering the development of e-commerce.

From production base and to farmers' processing, from agricultural cooperatives to business market, agricultural products finally move to the consumption market. Logistics-supply chain of agricultural products is clear, yet the distribution channel is not smooth. In Jiangxi Province, most rural areas are mountainous, so infrastructure construction needs to be fulfilled and the roads are so accessible that many high-quality products cannot be kept fresh and get to consumers. $\mathrm{C}$ customers from e-commerce are not able be satisfied for the low efficiency and fresh-keeping of agricultural products, thus having a bad impact on the development of e-commerce of agricultural cooperatives.

Professional talents are not enough in the field of e-commerce of agricultural cooperatives and also capital here is not adequate.

A few of agricultural cooperatives in Jiangxi Province take the mode of e-commerce. And one of important reasons is the lack of professionals. A handful of agricultural cooperatives will carry 
out e-commerce under the guidance of relevant experts. The truth is that the system of e-commerce fails to been managed by them and farmers do not accept necessary training cause the failure of e-commerce. At the same time, because of shortage of capital and participation of electronic-business enterprises, e-commerce of agricultural cooperatives in Jiangxi cannot develop comprehensively.

\section{Loose internal organization of the majority of agricultural cooperatives hinders the e-commerce.}

Farmers sell directly to internet customers individually with low-degree organization. Internal organization of part of agricultural cooperatives is so loose that it is difficult for them to form a joint force of collection of quality resources. In addition, effect of industrial scale is weakened. Some farmers' vision has been restricted, only considering their own interests and bringing to a negative impact for the e-commerce of agricultural cooperatives.

Use fish bone-diagram method to summarize above reasons, and the results can be shown in Figure 3-1:

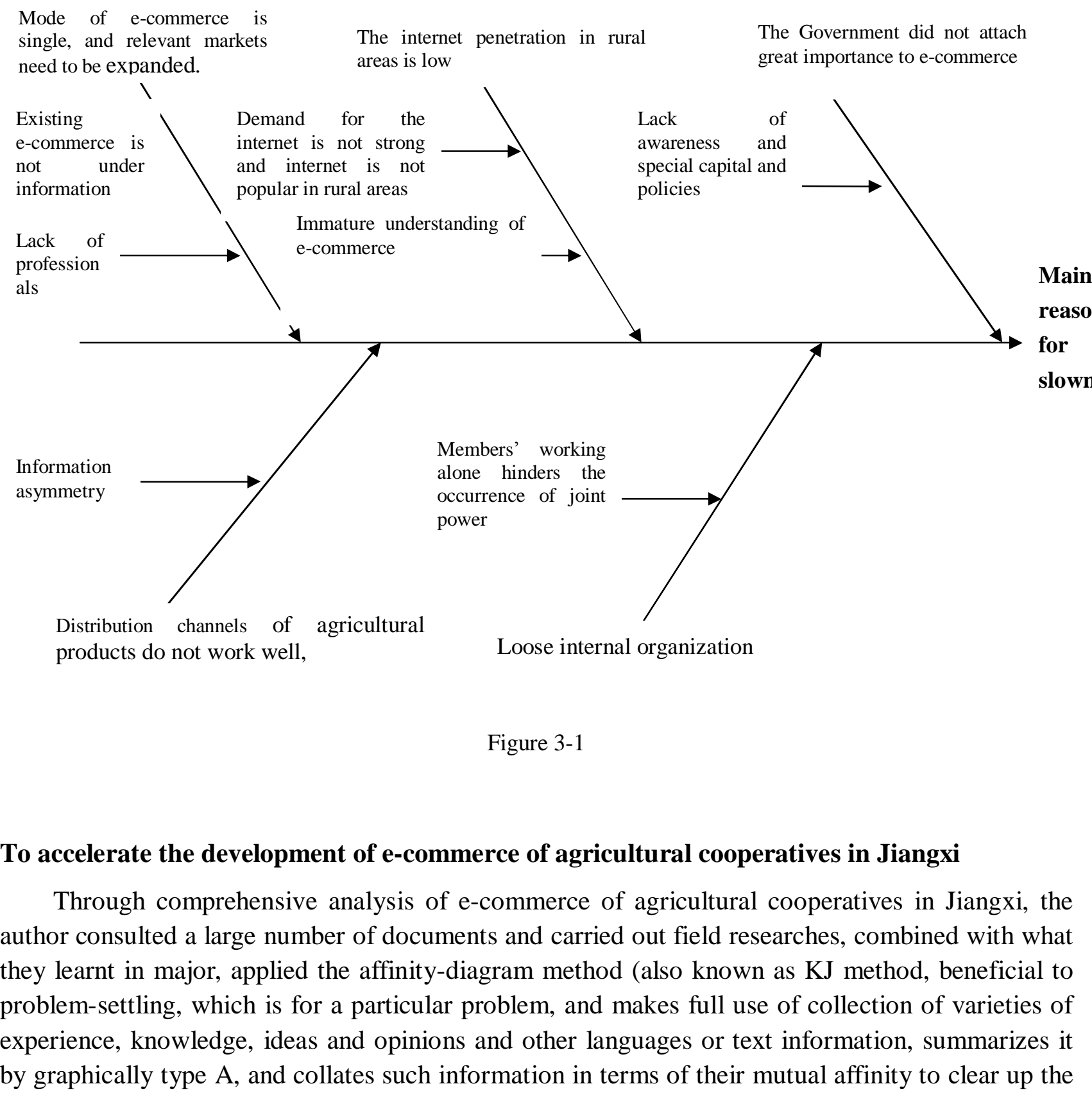


problem for seeking a common understanding), and pictured a diagram of type A, Figure 4-1:

\begin{tabular}{|c|c|c|c|}
\hline & \multicolumn{2}{|c|}{$\begin{array}{l}\text { Proposals on accelerating the development of } \\
\text { e-commerce of agricultural cooperatives in } \\
\text { Jiangxi }\end{array}$} & \multirow[b]{2}{*}{$\begin{array}{c}\text { Construction of } \\
\text { agricultural } \\
\text { cooperatives }\end{array}$} \\
\hline $\begin{array}{l}\text { Governmental } \\
\text { investment }\end{array}$ & IT Platform & $\begin{array}{c}\text { Market of } \\
\text { e-commerce }\end{array}$ & \\
\hline $\begin{array}{l}\text { Support of } \\
\text { policy }\end{array}$ & $\begin{array}{l}\text { Construction of } \\
\text { internet in rural } \\
\text { areas }\end{array}$ & $\begin{array}{l}\text { Disclosure of } \\
\text { product } \\
\text { information }\end{array}$ & $\begin{array}{l}\text { Coordination of } \\
\text { Market } \\
\text { resources }\end{array}$ \\
\hline $\begin{array}{l}\text { Design and } \\
\text { planning }\end{array}$ & $\begin{array}{l}\text { e-commerce of } \\
\text { consciousness }\end{array}$ & $\begin{array}{l}\text { Quality of } \\
\text { product } \\
\text { guarantee }\end{array}$ & $\begin{array}{l}\text { Information } \\
\text { Sharing }\end{array}$ \\
\hline $\begin{array}{l}\text { Department } \\
\text { service }\end{array}$ & $\begin{array}{l}\text { Popularization } \\
\text { of professional } \\
\text { technology }\end{array}$ & $\begin{array}{c}\text { Convenient } \\
\text { logistic of } \\
\text { product }\end{array}$ & $\begin{array}{l}\text { Professional } \\
\text { talents }\end{array}$ \\
\hline
\end{tabular}

Figure 4-1

Based on the results of affinity-diagram, the author puts forward proposals on accelerating the development of e-commerce of agricultural cooperatives as follows:

The Government must attach great importance to e-commerce of agricultural cooperatives and increase relevant investment

The government of Jiangxi Province should pay much attention to e-commerce of agricultural cooperatives, continue to increase relevant investment on e-commerce and enhance the standard of software and hardware development of e-commerce, thus improving the feasibility of extensive development of e-commerce of agricultural cooperatives in Jiangxi. The departments of government would better coordinate trade associations and research institutions to make the top-level design of e-commerce of agricultural cooperatives in Jiangxi, with rational planning and scientific development, and to make the formation of scale of e-commerce as soon as possible for improvement of the comprehensive efficiency of agriculture in Jiangxi.

To improve Internet penetration in rural areas, and strengthen farmers' consciousness of e-commerce in agricultural cooperatives

There is no doubt that we should focus on improvement of Internet penetration in rural areas. Also information network in rural areas is a key part of science-technology agricultural. When farmers have a better understanding of the network, we can make them to recognize the positive role of e-commerce of agricultural cooperatives and to stimulate farmers' awareness of e-commerce. Only in this way will e-commerce of agricultural cooperatives in Jiangxi grow effectively.

To expand in an all-round way on the market of e-commerce

We should continue to spare no efforts to develop applications of e-commerce market from single sales to information-sharing on comprehensive technical business consulting for achieving informatization of agricultural cooperatives. Through comprehensively informational feedback of e-commerce market, the farmers, according to market demand, rationally improve their agricultural products, introduce advanced technology, scientific processing and packaging for further enhancement of the value of agricultural products. Therefore, informatization of e-commerce market optimizes the allocation of resources of agricultural products in producing and processing, thus improving the overall economic efficiency. 
To promote the information disclosure of agricultural e-commerce market and to establish a traceability system of its quality

In terms of information asymmetry, it is time to accelerate the information disclosure of agricultural e-commerce market in Jiangxi for product sales, from production and processing to the final sales, should be open to consumers via the Internet, so that consumers will really know what they purchase. Meanwhile establishment and improvement of traceability system of quality would force farmers not to sell shoddy product as well as consumers. Only in this way would our society build a mechanism of mutual trust. In a word, basically removing the credit crisis of e-commerce will certainly promote benign development of e-commerce of agricultural cooperatives.

To continue to strengthen construction of infrastructure in rural areas, and to optimize the distribution channel of agricultural products

We continue to persist on enhancement of infrastructure construction in rural areas of Jiangxi, especially in remote areas, to ensure the openness of logistic channels. On one hand, make sure the hard condition of distribution channel. On the other, optimize the soft condition. For example, in the premise of ensuring the quality of agricultural products, reduce the circulation of approval procedures, thus saving time of logistics to ensure time and freshness. It is likely to free charge of some agricultural transport vehicles in times of high-speed road toll, so as to directly reduce logistics costs. We should try our best to promote distribution channel of agricultural products to maintain and enhance the comprehensively competitive advantages of e-commerce products of agricultural cooperatives in Jiangxi Province.

To focus on training relevant professionals, and to guarantee the effectiveness and sustainability of e-commerce of agricultural cooperatives

Focusing on cultivation of talents on e-commerce, especially for farmers from agricultural cooperatives contributes to their using of e-commerce system effectively. Recommends that each agricultural cooperative is equipped with professional staff to guide farmers to operate e-commerce system effectively and timely, to ensure the sustainability of e-commerce of agricultural cooperatives and to generalize e-commerce mode and make it enjoy popular support.

To make full use of market resources and to increase capital in the field of e-commerce of agricultural cooperatives

Coordinating all of market resources and enriching the capital in field of e-commerce of agricultural cooperatives as far as possible will surely promote cooperation between agriculture and enterprises. Companies are in charge of the e-commerce operations with financial and technical support. Departments of Government can also lead and coordinate the research institutes. Trade associations will construct e-commerce platform website for agricultural cooperatives so as to enhance comprehensive mechanism and platform of information-sharing, strengthen the quality in an all-round way, optimize the sales process, and accumulate the capital of e-commerce market, thus pushing the industrialization of agriculture to a new degree.

To enhance the level of internal management of agricultural cooperatives and to make e-commerce of agricultural cooperatives a large-scale one

It is necessary to enhance the level of management of agricultural cooperatives, to take advantages of mutual aid of agricultural cooperatives and to optimize resource allocation. And it's time to get rid of small-farmers thought and to work together for exchange of information and needs. For example, if a member receives a sum of agricultural orders, he is unable to complete it in a specified time. Naturally he would seek to work with other members of the cooperative for real development and cooperation, mutual benefit and win-win situation. Only in this way can we achieve a large-scale development of e-commerce of Jiangxi agricultural cooperatives as soon as 
possible.

\section{Concluding remarks}

The e-commerce model of Jiangxi agricultural cooperatives is an effective way to promote the development of agricultural informatization in Jiangxi. Characteristics, such as no limitation of borders, time and space, are possessed by internet and internet-based e-commerce, which push Jiangxi agricultural products to into the international market with the help of e-commerce [5]. Based on the actual situation of development of e-commerce of agricultural cooperatives in Jiangxi, proposals the thesis puts forward on the acceleration of e-commerce of agricultural cooperatives in Jiangxi will undoubtedly promote a sound and rapid development of e-commerce of agricultural cooperatives in Jiangxi Province.

With the development of agriculture in China, agricultural cooperatives will grow much stronger and stronger. In virtue of modern information technology, promotion on the construction of e-commerce of agricultural cooperatives and continuous improvement of the efficiency of production and management of agricultural cooperatives will provide a broader space for the development of agricultural cooperatives platform, thus continuously enhancing the modernization, technicalization and informatization of China's agriculture.

\section{Acknowledgements}

This work was financially supported by the Education Department of Humanities and Social Sciences in Jiangxi Province of key projects: support for the Central Soviet Area Gannan characteristics of industrial cluster formation mechanism (JD1536).

\section{References}

[1] Bao Bin. Design and implementation of e-commerce system of agricultural cooperatives [J] Network Information of Agriculture T, 2014 (5): 107--109

[2] Huang Yaochun, Wu Xinghua. Empirical analysis of agricultural products and potential products in Jiangxi. [J] Statistical Yearbook of Jiangxi, 2002: 483--487.

[3] Liu Junjun. Agricultural cooperatives and networks---exploration of e-commerce model in rural areas [J] Jilin Economic and Management Cadre College Journal, 2014 (1): 35-38.

[4] Liu Litao. On the new mode of agricultural informatization---e-commerce model between agriculture and cooperation [J] Shanxi Science and Technology, 2014 (4): 1-2

[5] Shen Jiujiu, Liu Jingqi. Reflections on informatization to promote the development of agricultural in Jiangxi Province [J]. Jiangxi Agricultural University Journal (Social Science Edition), 2004 (3): 15-17 